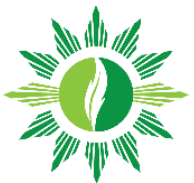

\title{
Analisis Faktor Risiko Gangguan Muskuloskeletal Pada Karyawan Kependidikan STIKES Suaka Insan
}

\author{
Utomo Wicaksono ${ }^{1 *}$, Kristina Novita Leluni ${ }^{1}$, Ninuk Kusumawati ${ }^{1}$, Bernadus Sadu ${ }^{1}$, \\ Dadan Prayogo ${ }^{1}$, Michaela Putri Kasinem Issohone ${ }^{1}$
}

${ }^{1}$ Sekolah Tinggi IImu Kesehatan Suaka Insan, Indonesia

"Korespondensi: tomwicaksono@gmail.com

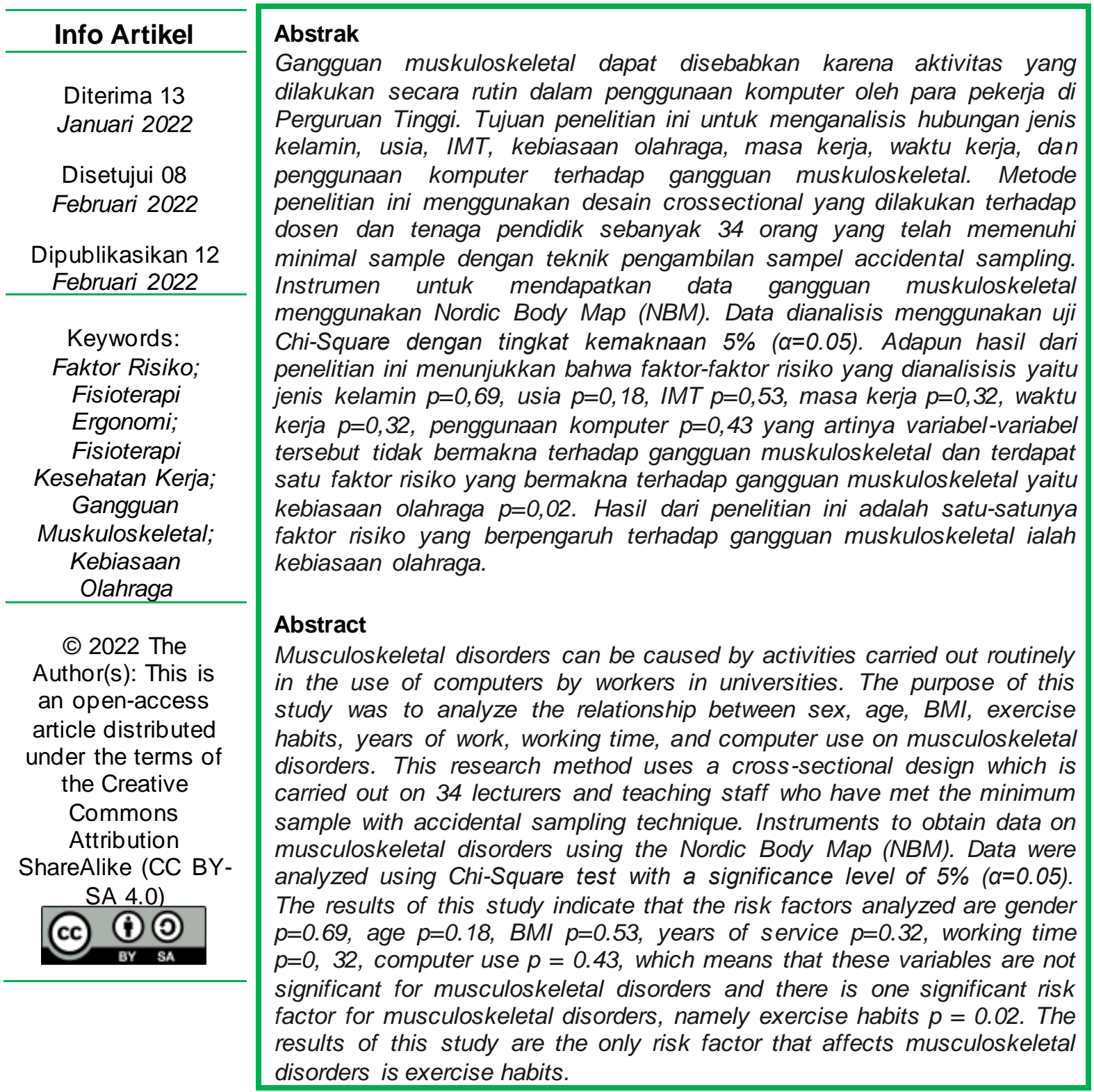




\section{Pendahuluan}

Gangguan muskuloskeletal terkait pekerjaan merupakan jenis masalah kesehatan yang paling umum terjadi pada miliaran orang di selu ruh dunia (Chang et al., 2012; Lei et al., 2005). Kondisi ini rentan terjadi pada banyak negara berkembang dan maju (Safarian et al., 2019) yang menyebabkan meningkatnya ketidakhadiran kerja, biaya perawatan kesehatan, biaya kompensasi, sehingga mempengaruhi perkembangan organisasi (Naik \& Khan, 2020) serta produktivitas pekerja (Albeeli et al., 2020). Spektrum gangguan muskuloskeletal mencakup kondisi inflamasi dan degeneratif yang mempengaruhi otot, tendon, ligamen, sendi, saraf perifer, dan pembuluh darah pendukung (Da Costa \& Vieira, 2010; Punnett \& Wegman, 2004). Gejala gangguan muskuloskeletal termasuk nyeri, mati rasa, kesemutan, sakit, kaku, atau rasa terbakar. Bagian tubuh yang paling umum terkena gangguan muskuloskeletal ialah pinggang, leher, bahu, lengan bawah, dan tangan (Punnett \& Wegman, 2004).

Pada tahun 2018 staf Universitas Kerman melaporkan angka kejadian gangguan muskuloskeletal dalam 12 bulan terakhir sebesar $72 \%$ bagian punggung bawah, $55,2 \%$ bagian leher, $51,6 \%$ bagian bahu, 44,8\% bagian lutut, $27,2 \%$ bagian punggung atas, $24 \%$ bagian pergelangan tangan, $24 \%$ bagian pinggul dan paha, $10,4 \%$ bagian pergelangan kaki dan kaki, 6,8\% bagian siku (Mohammadipour et al., 2018). Prevalensi gangguan muskuloskeletal juga ditemukan tinggi pada pekerja kantoran di kota Putrajaya-Malaysia yaitu sebesar 83,7\%. Punggung bawah, bahu, dan leher merupakan bagian tubuh yang paling ban yak dikeluhkan mengalami gangguan muskuloskeletal, masing-masing 58,5\%, 48,5\%, dan $43 \%$ (Albeeli et al., 2020). Negara Indonesia sendiri gangguan kesehatan yang paling umum dialami pekerja menurut survei yang dilakukan terhadap 9.482 pekerja ialah gangguan muskuloskeletal (16\%) dibandingkan dengan gangguan kesehatan lainnya seperti kardiovaskuler (8\%), gangguan syaraf (6\%), gangguan pernapasan (3\%) dan gangguan telinga hidung tenggorokan (1,5\%) (Departemen Kesehatan Republik Indonesia, 2005).

Secara umum gangguan muskuloskeletal pada pekerja dapat disebabkan karena multifaktorial seperti faktor individu, faktor pekerjaan, dan faktor lingkungan (AlOmar et al., 2021). Pada pekerja kantoran gangguan muskuloskeletal sangat berhubungan dengan lama penggunaan komputer dan risiko meningkat terus seiring penambahan waktu dalam menggunakan komputer. Bagian tubuh yang rentan mengalami gangguan terkait dengan penggunaan komputer ialah punggung, leher, bahu, dan pergelangan/tangan (Alavi et al., 2016; Ardahan \& Simsek, 2016). Selain itu, dari faktor individu yang berhubungan dengan gangguan muskuloskeletal pada pekerja kantoran meliputi jenis kelamin perempuan, usia lebih tua, IMT (indeks masa tubuh) lebih dari ideal, tidak rutin olahraga, masa kerja lebih lama, dan waktu kerja lebih panjang (Amit \& Malabarbas, 2020; Karwan et al., 2015; Mohan et al., 2015; Sirajudeen et al., 2018).

Karayawan kependidikan baik dosen maupun tenaga pendidik di STIKES Suaka Insan merupakan pekerja kantoran yang tidak terlepas dalam melakukan pekerjaan dengan menggunakan komputer. Pekerja berjenis kelamin perempuan sangat mendominasi dibanding dengan laki-laki, fenomena tersebut menimbulkan asumsi peneliti bahwa tingginya angka kejadian gangguan muskuloskeletal pada karyawan kependidikan STIKES Suaka Insan. Dengan demikian peneliti mempertimbangkan perlunya melakukan penelitian yang bertujuan untuk 
mendeskripsikan angka kejadian dan menganalisis hubungan jenis kelamin, usia, IMT, kebiasaan olahraga, masa kerja, waktu kerja, dan penggunaan komputer terhadap gangguan muskuloskeletal.

\section{Metode Penelitian}

Penelitian menggunakan desain crossectional. Sampel penelitian ini melibatkan sebanyak 34 orang, terdiri dari dosen dan tenaga pendidik yang telah memenuhi minimal sample berdasarkan perhitungan rumus Slovin dengan ju mlah populasi diketahui. Teknik penambilan sampel dalam penelitian ini menggunakan accidental sampling. Penelitian dilakukan pada bulan Oktober 2021 sampai bulan Januari 2022. Instrumen yang digunakan meliputi: Nordic Body Map (NBM) untuk mengukur gangguan muskuloskeletal; timbangan berat badan untuk mengukur berat badan, microtoise stature meter untuk mengukur tinggi badan; serta kuesioner terkait karakteristik individu seperti, jenis kelamin, usia, masa kerja, kebiasaan olahraga rutin yang dilakukan/minggu, masa kerja, waktu kerja/minggu, dan lama penggunaan komputer/hari. Data dianalisis dengan bantuan perangkat lunak Statistical Package for The Social Science (SPSS) 26.0 menggunakan uji Chi-Square jika tidak ada Expected Count $<5$ dan uji Fisher's Exact jika ada Expected Count < 5 dengan tingkat kemaknaan 5\% ( $\alpha=0.05)$ serta Odd Ratio (OR) untuk menilai seberapa besar pengaruh yang dihasilkan variabel bebas terhadap varibel terikat dengan interpretasi $\mathrm{OR}=1$ (tidak memiliki asosiasi), $\mathrm{OR}>1$ (memiliki asosiasi positif), $\mathrm{OR}<1$ (memiliki asosiasi negatif).

\section{Hasil dan Pembahasan}

\subsection{Hasil}

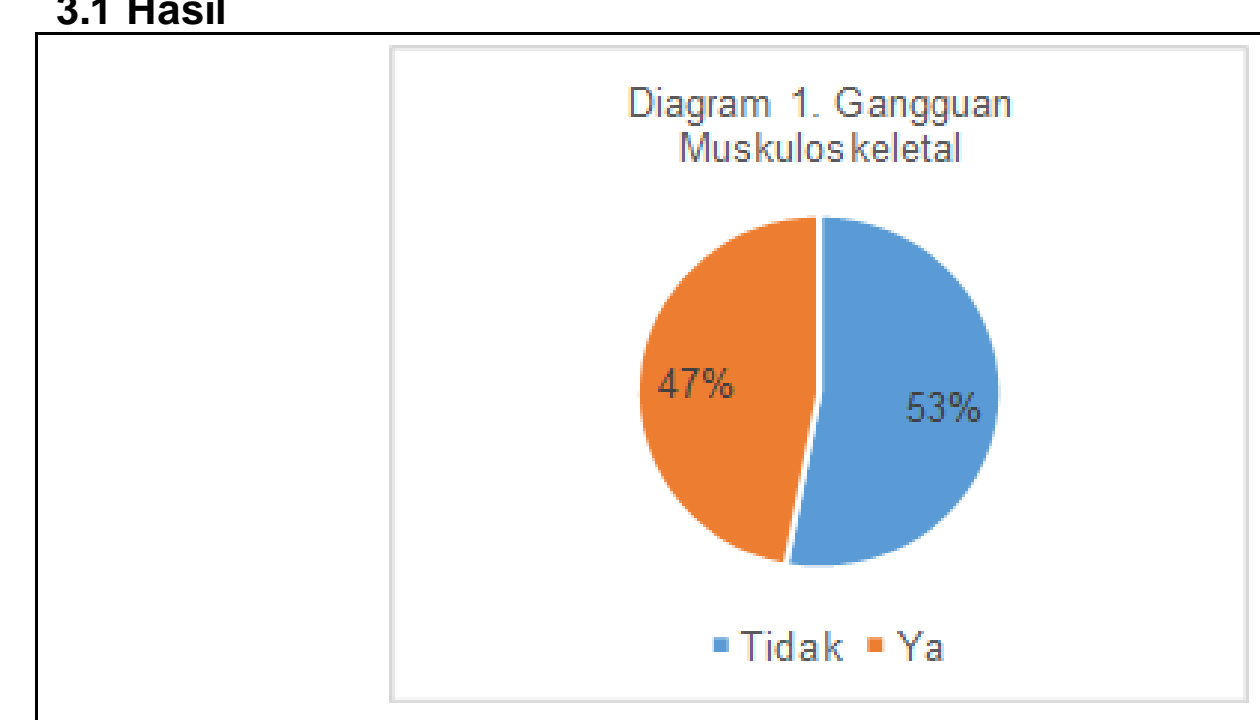

Gambar 1. Diagram Gangguan Muskuloskeletal 


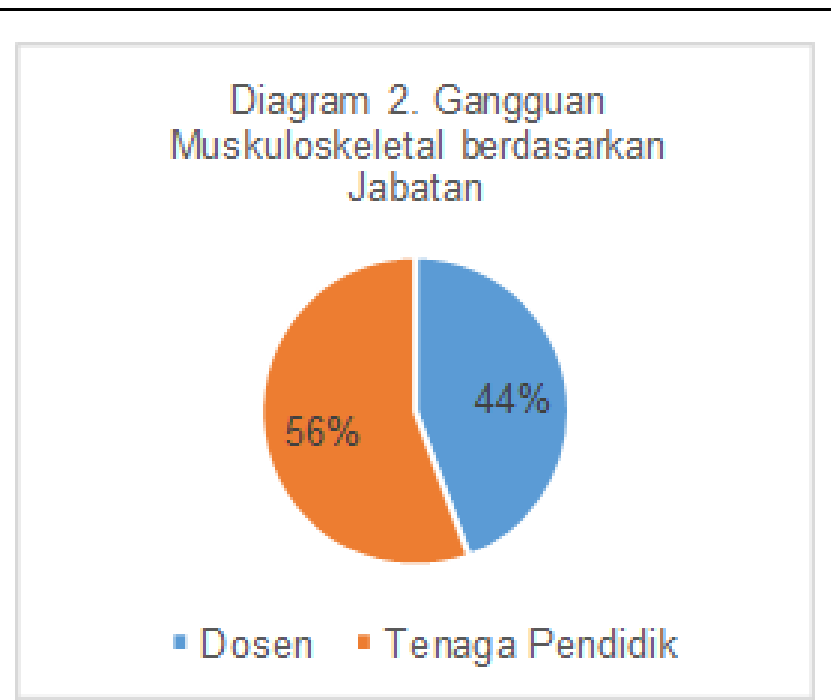

Gambar 2. Diagram gangguan Muskuloskeletal berdasarkan jabatan

Diagram 1 menunjukkan hampir setengah dari total responden yang dilibatkan mengalami gangguan muskuloskeletal yaitu sebesar $47 \%$. Diagram 2 distribusi gangguan muskuloskeletal berdasarkan jabatan pada Tenaga pendidik ditemukan lebih banyak yaitu sebesar $56 \%$ dan dosen sebesar $44 \%$.

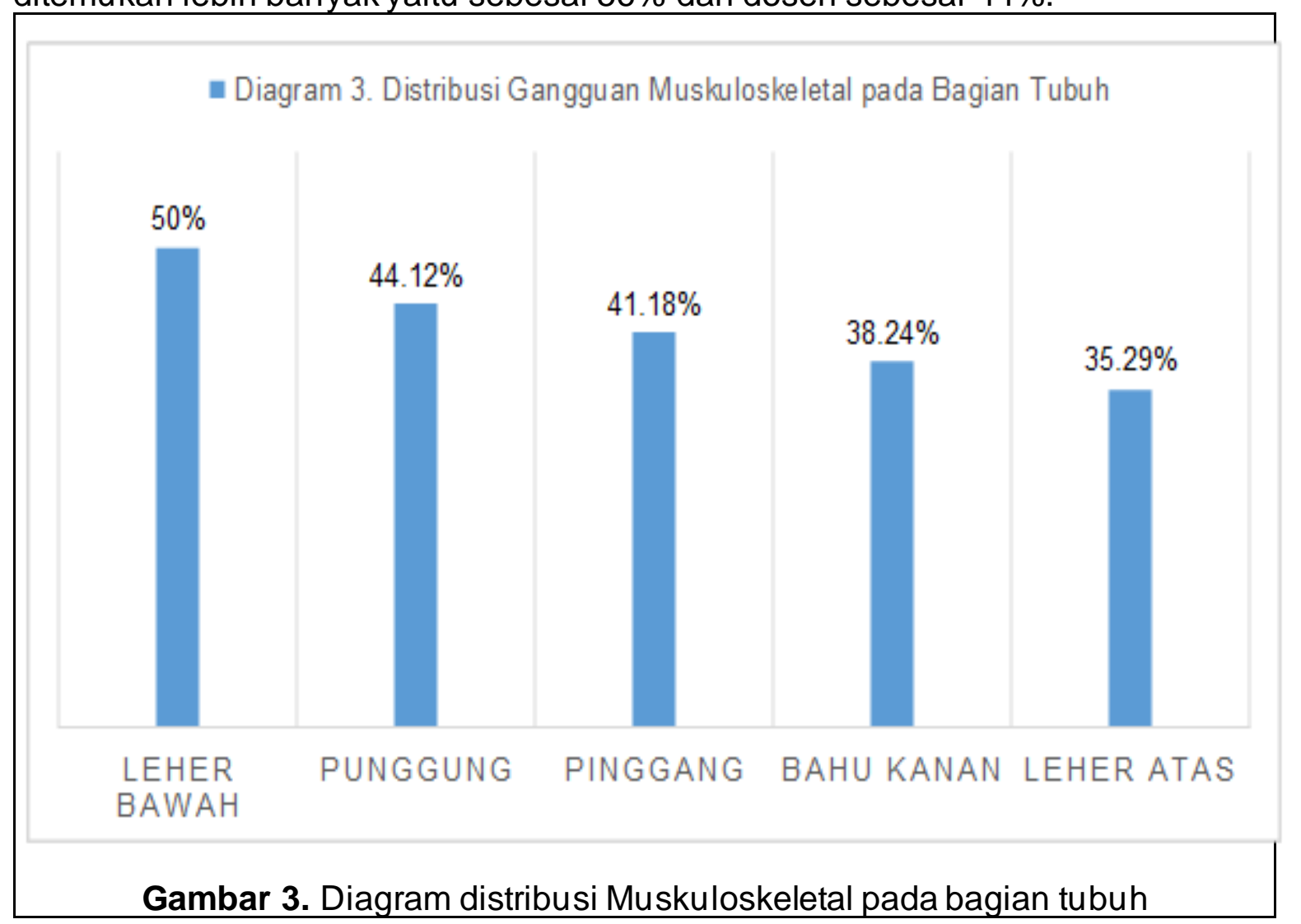

Diagram 3 menunjukkan bagian tubuh yang paling banyak dikeluhkan mengalami gangguan muskuloskeletal yaitu leher bawah $50 \%$, diikuti dengan keluhan pada punggung $44,12 \%$, pinggang $41,18 \%$, bahu kanan $38,24 \%$, dan leher bagian atas $35,29 \%$. 
Tabel 1. Analisis Faktor Gangguan Muskuloskeletal

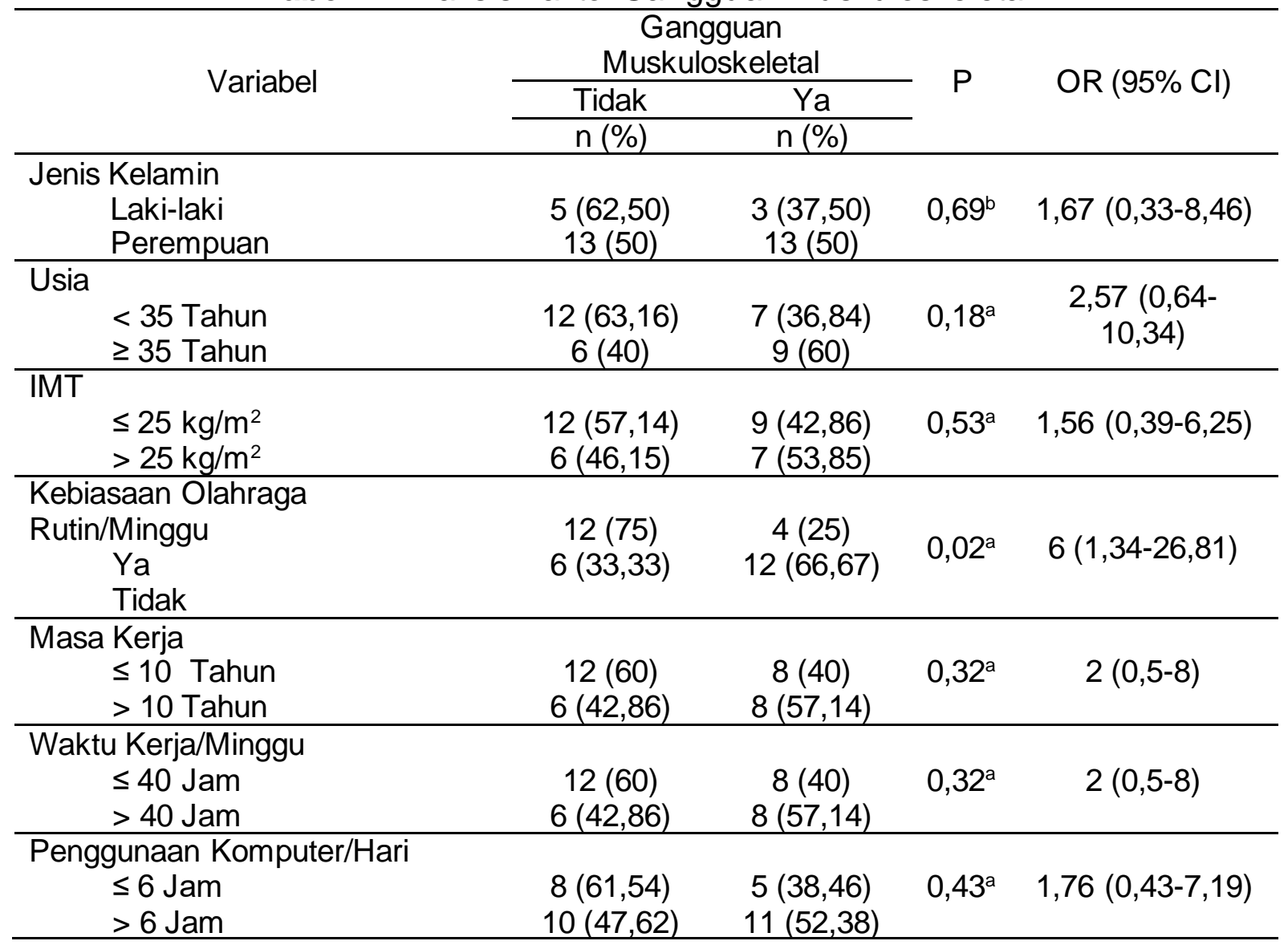

${ }^{a}$ Chi Square Test, bisher's Exact Test

Tabel 1 menunjukkan pekerja perempuan (50\%) memiliki proporsi gangguan muskuloskeletal lebih besar dibanding laki-laki (37,50\%), pekerja usia $\geq 35$ tahun $(60 \%)$ memiliki proporsi gangguan muskuloskeletal lebih besar dibanding usia $<35$ tahun (36,84\%), pekerja dengan IMT > $25 \mathrm{~kg} / \mathrm{m}^{2}(53,85 \%)$ memiliki proporsi gangguan muskuloskeletal lebih besar dibanding pekerja dengan IMT $\leq 25 \mathrm{~kg} / \mathrm{m}^{2}$ $(42,86 \%)$, pekerja yang tidak melakukan olahraga rutin/minggu $(66,67 \%)$ memiliki proporsi gangguan muskuloskeletal lebih besar dibanding pekerja yang melakukan olahraga rutin/minggu (25\%), pekerja dengan masa kerja > 10 tahun $(57,14 \%)$ memiliki proporsi gangguan muskuloskeletal lebih besar dibanding pekerja dengan masa kerja $\leq 10$ tahun $(40 \%)$, pekerja dengan waktu kerja/minggu $>40$ jam $(57,14 \%)$ memiliki proporsi gangguan muskuloskeletal lebih besar dibanding pekerja dengan waktu kerja/minggu $\leq 40$ jam(40\%), dan bekerja menggunakan komputer > 6 jam $(52,38 \%)$ memiliki proporsi gangguan muskuloskeletal lebih besar dibanding bekerja menggunakan komputer $\leq 6$ jam $(38,46 \%)$. Berdasarkan analisis ditemukan ada hubungan yang bermakna antara kebiasaan olahraga dengan gangguan muskuloskeletal $(p=0,02<0,05)$, sehingga pekerja yang tidak melakukan olahraga rutin/minggu lebih berisiko 6 kali (95\% Cl=1,34-26,81) mengalami gangguan muskuloskeletal. Sedangkan karakteristik individu seperti jenis kelamin, usia, IMT, masa kerja, waktu kerja, dan lama penggunaan komputer ditemukan tidak ada hubungan yang bermakna terhadap gangguan muskuloskeletal $(p>0,05)$. 


\subsection{Pembahasan}

Pada penelitian ini, berdasarkan hasil uji statistik terhadap variabel jenis kelamin, usia, IMT, kebiasaan olahraga, masa kerja, waktu kerja, dan lama penggunaan komputer hanya satu variabel yang ditemukan sebagai faktor risiko secara bermakna terhadap gangguan muskuloskeletal, yaitu kebiasaan olahraga. Pekerja yang melakukan kebiasaan olahraga secara rutin perminggu diyakini sebagai faktor pencegah terhadap terjadinya gangguan muskuloskeletal dibandingkan dengan yang tidak memiliki kebiasaan olahraga akan meningkatkan risiko 6 kali terhadap terjadinya gangguan muskuloskeletal $(p=0,02)$. Penelitian yang konsisten dengan temuan ini menjelaskan bahwa melakukan olahraga secara rutin mencegah otot rentan terhadap kelelahan karena efek dari peningkatan metabolisme tubuh, meningkatkan penyerapan oksigen, meningkatkan suhu tubuh dan meningkatkan aliran darah ke tendon, otot, dan ligamen, sehingga meningkatkan nutrisi seluler. Seiring waktu, lebih banyak olahraga dapat membuat otot lebih kuat dengan tingkat daya tahan yang meningkat dan mengurangi risiko terjadinya cedera (Karwan et al., 2015). Meski begitu, temuan ini bertolak belakang dengan penelitian Haljaste dan Unt (2010) bahwa tidak ada hubungan yang bermakna antara prevalensi gangguan muskuloskeletal dan olahraga di antara mantan atlet di Estonia.

Jenis kelamin ditemukan bukan sebagai faktor risiko terhadap gangguan muskuloskeletal yang dialami pekerja $(p=0,69)$. Temuan ini konsisten dengan penelitian Karwan (2015) bahwa jenis kelamin tidak memiliki hubungan yang bermakna terhadap gangguan muskuloskeletal, walaupun persentase terjadinya gangguan muskuloskeletal lebih tinggi pada perempuan (70\%) dibanding laki-laki $(60 \%)$. Shariat (2018) juga mendukung temuan tersebut bahwa tidak ada hubungan yang bermakna antara jenis kelamin dan keluhan nyeri akibat adanya gangguan muskuloskeletal pada leher, bahu, dan pinggang yang dialami oleh pekerja kantoran yang erat kaitannya dengan penggunaan komputer. Penelitian lain yang bertentangan dengan temuan ini menyatakan bahwa jenis kelamin perempuan memiliki risiko sebesar 1,13 kali secara bermakna terhadap terjadinya gangguan muskuloskeletal dibanding laki-laki, paling tinggi dirasakan pada bagian bahu kanan (62,62\%), punggung (62,62\%), bahu kiri $(54,85 \%)$, pinggang $(46,60 \%)$, dan leher atas $(42,72 \%)$. Secara fisiologis kemampuan atau kekuatan otot perempuan lebih rendah daripada laki-laki karena serabut otot yang ada pada perempuan lebih kecil dibandingkan dengan laki-laki (Lestari et al., 2020). Penelitian lainnya menyimpulkan bahwa kemampuan otot laki-laki 1,5-2 kali lebih kuat dari perempuan. Laki-laki sudah lanjut usia memiliki kemampuan otot setara dengan perempuan muda (Danneskiold-Samsøe et al., 2009).

Penelitian sebelumnya telah membuktikan usia merupakan faktor risiko terhadap terjadinya gangguan muskuloskeletal. Seiring bertambahnya usia akan terjadi degenerasi pada sistem muskuloskeletal, seperti hilangnya massa otot dan kekuatan otot secara progresif (sarcopenia), dan terjadi penurunan kemampuan regeneratif. Perubahan ini terkait dengan gangguan metabolisme otot, termasuk disfungsi mitokondria (Nawrocka et al., 2019). Pada penelitian ini ditemukan hal yang tidak konsisten bahwa usia tidak berisiko terhadap terjadinya gangguan muskuloskeletal $(p=0,18)$. Penelitian sebelumnya yang mendukung temuan ini berasal dari negara Malaysia yang bertujuan untuk menguji hubungan usia terhadap gangguan muskuloskeletal pada karyawan kependidikan, hasil penelitian 
tersebut ditemukan tidak ada hubungan yang bermakna antara usia dan gangguan muskuloskeletal (Mohan et al., 2015).

The Global Burden of Disease Study tahun 2016 menyatakan bahwa obesitas atau IMT berlebih merupakan faktor risiko untuk peningkatan prevalensi gangguan muskuloskeletal, lebih khusus nyeri pinggang (Vos et al., 2017). IMT normal 90\% berpengaruh terhadap pengurangan risiko gangguan muskuloskeletal (Walsh et al., 2018). Obesitas atau IMT berlebih dapat menyebabkan tekanan biomekanik pada sendi yang menahan beban, di mana beban berlebih dapat mengubah gaya berjalan dan postur seseorang, sehingga menciptakan lingkungan biomekanik yang merugikan (AlOmar et al., 2021). Penelitian kali ini ditemukan IMT tidak berisiko terhadap terjadinya gangguan muskuloskeletal $(p=0,53)$. Pada penelitian serupa juga ditemukan IMT bukan sebagai faktor risiko terhadap gangguan muskuloskeletal. Dari kesembilan bagian tubuh yang diteliti termasuk leh er, bahu, siku, pergelangan/tangan, punggung, pinggang, panggul, lutut, pergelangan/kaki, IMT hanya sebagai faktor risiko yang bermakna terhadap gangguan pada bahu sedangkan kedelapan bagian tubuh lainnya ditemukan IMT tidak sebagai faktor risiko gangguan musku loskeletal secara bermakna (Sirajudeen et al., 2018).

Masa kerja ditemukan tidak berisiko terhadap terjadinya gangguan muskuloskeletal $(p=0,32)$. Hasil penelitian ini konsisten dengan penelitian yang dilakukan oleh Mohan (2015) bahwa pada pekerja yang memiliki masa kerja lebih lama ditemukan lebih banyak mengalami gangguan muskuloskeletal dibandingkan karyawan kependidikan yang memiliki masa kerja kurang dari 11 tahun dengan selisih persentase sebesar 8,79\%, namun ditemukan tidak bermakna sebagai faktor risiko terhadap gangguan muskuloskeletal. Penelitian oleh Ferusgel (2019) juga mendukung penelitian ini bahwa semakin lama masa kerja justru membuat semakin rendahnya angka kejadian gangguan muskuloskeletal, pekerja pengguna komputer dapat beradaptasi dengan aktivitas kerjanya, meningkatkan pengalaman dan keterampilan, serta meningkatkan kewaspadaan terhadap penyakit akibat kerja. Hasil penelitian ini bertentangan dengan penelitian sebelumnya yang menemukan bahwa semakin bertambahnya masa kerja akan berisiko terhadap gangguan muskuloskeletal. Seiring bertambahnya masa kerja berkaitan dengan kejadian kelelahan kronis yang dirasakan pekerja, sehingga menyebabkan akumulasi stres pada otot dan tendon yang menimbulkan punurunan aliran darah yang memicu terjadinya iskemia jaringan dan nyeri (AIOmar et al., 2021).

Waktu kerja tidak memiliki hubungan terhadap kejadian gangguan muskuloskeletal $(p=0,32)$. Temuan ini didukung oleh Amit (2020) bahwa tidak ada hubungan yang bermakna antara waktu kerja dan gangguan muskuloskeletal. Penelitian Anjanny (2019) membantah hasil temuan ini bahwa lama kerja merupakan faktor risiko yang bermakna terhadap kejadian gangguan muskuloskeletal. Teori yang diungkapkan bahwa semakin panjang waktu kerja yang dijalani oleh pekerja akan meningkatkan beban kerja, semakin lama pula waktu yang diperlukan untuk melakukan pemulihan, serta menyebabkan berkurangnya kesempatan untuk melakukan istirahat yang memicu rasa ketidaknyaman fisik yang akan berkembang menjadi gangguan muskuloskeletal.

Tidak terdapat hubungan yang bermakna antara lama penggunaan komputer dengan gangguan muskuloskeletal pada karyawan kependidikan $(p=0,43)$. Hasil penelitian ini sejalan dengan yang dilakukan oleh Situmorang (2020) bah wa tidak ada hubungan antara lama penggunaan komputer dengan gangguan 
muskuloskeletal. Hal yang diyakini sebagai pencegah kejadian gangguan muskuloskeletal pada fenomena ini ialah pekerja menjaga postur tubuh dan melakukan istirahat di sela kerja meskipun menggunakan komputer dalam waktu yang lama. Hasil temuan ini tidak sejalan dengan peneltian Mohan (2015) dan Sirajudeen (2018) yang menemukan bahwa semakin lama menggunakan komputer berisiko terhadap gangguan muskuloskeletal pada leher, punggung, pinggang, panggul, dan pergelangan/tangan secara bermakna. Gangguan muskuloskeletal pada pengguna komputer berkaitan dengan faktor ergonomi seperti gerakan repetitif rotasi dan menunduk pada leher untuk melihat layar komputer, keyboard, dan dokumen secara bergantian serta ekstremitas atas untuk aktivitas membolak-balik dokumen, mengetik, dan menggerakkan mouse yang menyebabkan otot tegang. Bekerja di depan komputer juga membutuhkan postur statis pada tubuh bagian atas yang akan menyebabkan penekanan pada otot-otot dan jaringan lunak di sekitarnya sehingga terjadinya iskemia dan menimbulkan rasa nyeri (Mardiyanti, 2021).

Keterbatasan penelitian ini, peneliti tidak melakukan pengontrolan terhadap variabel aspek pekerjaan seperti beban kerja dan postur kerja sehingga terdapat nilai yang bervariasi pada responden yang memungkinkan dapat mengganggu hasil penelitian. Peneliti juga tidak mengkaji frekuensi kebiasaan olahraga yang dilakukan oleh responden selama seminggu sehingga peneliti kesulitan untuk memberikan rekomendasi dosis olahraga yang ideal untuk mencegah gangguan muskuloskeletal. Penelitian selanjutnya diharapkan dapat melakukan analisis yan g lebih komprehensif terhadap faktor risiko yang berasal dari faktor personal, faktor pekerjaan, dan faktor lingkungan terhadap gangguan muskuloskeletal yang dirasakan oleh karyawan kependidikan.

\section{Kesimpulan}

Angka kejadian gangguan muskuloskeletal secara keseluruhan pada karyawan kependidikan ditemukan sebesar 47\%. Gangguan lebih banyak dirasakan pada leher bawah 55\%, punggung 44,12\%, pinggang 41,18\%, bahu kanan 38,24\%, dan leher atas 35,29\%. Dari hasil analisis yang dilakukan satusatunya faktor risiko gangguan muskuloskeletal secara bermakna ialah tidak melakukan kebiasaan olahraga secara rutin. Saran untuk penelitian selanjutnya diharapkan dapat melakukan analisis yang lebih komprehensif terhadap faktor risiko yang berasal dari faktor personal, faktor pekerjaan, dan faktor lingkungan terhadap gangguan muskuloskeletal yang dirasakan oleh karyawan kependidikan.

\section{Ucapan Terima Kasih}

Terimakasih kami ucapkan kepada STIKES Suaka Insan yang telah memberikan dukungan baik secara moral, finansial, dan kesediaannya menjadi responden sehingga kegiatan penelitian ini dapat berjalan dengan lancar dan penelitian ini dapat menjadi sebuah artikel yang dipublikasikan.

\section{Daftar Pustaka}

Alavi, S. S., Abbasi, M., \& Mehrdad, R. (2016). Risk factors for upper extremity musculoskeletal disorders among office workers in qom province, iran. Iranian Red Crescent Medical Journal, 18(10), e29518.

Albeeli, A., Tamrin, S. B. M., Guan, N. Y., \& Karuppiah, K. (2020). Musculoskeletal disorders and its association with self-reported productivity: a cross-sectional 
study among public office-workers in Putrajaya, Malaysia. Malaysian Journal of Medicine and Health Sciences, 16(4), 272-279.

AlOmar, R. S., AIShamlan, N. A., Alawashiz, S., Badawood, Y., Ghwoidi, B. A., \& Abugad, H. (2021). Musculoskeletal symptoms and their associated risk factors among Saudi office workers: a cross-sectional study. BMC Musculoskeletal Disorders, 22(1), 1-9.

Amit, L. M., \& Malabarbas, G. T. (2020). Prevalence and risk-factors of musculoskeletal disorders among provincial high school teachers in the philippines. Journal of UOEH, 42(2), 151-160.

Anjanny, A., Ferusgel, A., \& Siregar, D. M. S. (2019). Keluhan musculoskeletal disorders (MSDs) pada pekerja pengguna komputer di badan pusat statistik provinsi sumatera utara. Jurnal Kesehatan Global, 2(1), 45-51.

Ardahan, M., \& Simsek, H. (2016). Analyzing musculoskeletal system discomforts and risk factors in computer-using office workers. Pakistan Journal of Medical Sciences, 32(6), 1425-1429.

Chang, J. H., Wu, J. D., Liu, C. Y., \& Hsu, D. J. (2012). Prevalence of musculoskeletal disorders and ergonomic assessments of cleaners. American Journal of Industrial Medicine, 55(7), 593-604.

Da Costa, B. R., \& Vieira, E. R. (2010). Risk factors for work-related musculoskeletal disorders: a systematic review of recent longitudinal studies. American Journal of Industrial Medicine, 53(3), 285-323.

Danneskiold-Samsøe, B., Bartels, E. M., Bülow, P. . M., Lund, H., Stockmarr, A., Holm, C. C., Wätjen, I., Appleyard, M., \& Bliddal, H. (2009). Isokinetic and isometric muscle strength in a healthy population with special reference to age and gender. Acta Physiologica, 197(673), 1-68.

Departemen Kesehatan Republik Indonesia. (2005). Profil masalah kesehatan pekerja di indonesia tahun 2005.

Haljaste, K., \& Unt, E. (2010). Relationships between physical activity and musculoskeletal disorders in former athletes. Collegium Antropologicum, 34(4), 1335-1340.

Karwan, M. K., Azuhairi, A. A., \& Hayati, K. S. (2015). Predictors of upper limb disorders among a public university workers in malaysia. International Journal of Public Health and Clinical Sciences, 2(3), 133-150.

Lei, L., Dempsey, P. G., Xu, J. G., Ge, L. N., \& Liang, Y. X. (2005). Risk factors for the prevalence of musculoskeletal disorders among Chinese foundry workers. International Journal of Industrial Ergonomics, 35(3), 197-204.

Lestari, P. W., Purba, Y. S., \& Tribuwono, A. C. (2020). Comparison of musculoskeletal disorder risk based on gender in high school students. KEMAS: Jurnal Kesehatan Masyarakat, 16(1), 53-60.

Mardiyanti, F. (2021). Pengukuran risiko kerja dan keluhan muskuloskeletal pada pekerja pengguna komputer. Ournal of Innovation Research and Knowledge, 1(3), 333-346.

Mohammadipour, F., Pourranjbar, M., Naderi, S., \& Rafie, F. (2018). Work-related 
musculoskeletal disorders in Iranian office workers: prevalence and risk factors. Journal of Medicine and LLfe, 11(4), 328-333.

Mohan, V., Justine, M., Jagannathan, M., Aminudin, S. B., \& Johari, S. H. B. (2015). Preliminary study of the patterns and physical risk factors of work-related musculoskeletal disorders among academicians in a higher learning institut. Journal of Orthopaedic Science, 20(2), 410-417.

Naik, G., \& Khan, M. R. (2020). Prevalence of MSDs and postural risk assessment in floor mopping activity through subjective and objective measures. Safety and Health at Work, 11(1), 80-87.

Nawrocka, A., Niestrój-Jaworska, M., Mynarski, A., \& Polechoński, J. (2019). Association between objectively measured physical activity and musculoskeletal disorders, and perceived work ability among adult, middleaged and older women. Clinical Interventions in Aging, 14.

Punnett, L., \& Wegman, D. H. (2004). Work-related musculoskeletal disorders: the epidemiologic evidence and the debate. Journal of Electromyography and Kinesiology, 14(1), 13-23.

Safarian, M. H., Rahmati-Najarkolaei, F., \& Mortezapour, A. (2019). A comparison of the effects of ergonomic, organization, and education interventions on reducing musculoskeletal disorders in office workers. Health Scope, 8(1), 19.

Shariat, A., Cardoso, J. R., Cleland, J. A., Danaee, M., Ansari, N. N., Kargarfard, M., \& Mohd Tamrin, S. B. (2018). Prevalence rate of neck, shoulder and lower back pain in association with age, body mass index and gender among malaysian office workers. Work, 60(2), 191-199.

Sirajudeen, M. S., Alaidarous, M., Waly, M., \& Alqahtani, M. (2018). Work-related musculoskeletal disorders among faculty members of college of applied medical sciences, majmaah university, saudi arabia: a cross-sectional study. International Journal of Health Sciences, 12(4), 18-25.

Situmorang, C. K., Widjasena, B., \& Wahyuni, I. (2020). Hubungan antara durasi dan postur tubuh penggunaan komputer terhadap keluhan neck pain pada tenaga kependidikan fakultas kesehatan masyarakat universitas dipon egoro. Jurnal Kesehatan Masyarakat, 8(5), 672-678.

Vos, T., Abajobir, A. A., Abate, K. H., Abbafati, C., Abbas, K. M., Abd-Allah, F., Abdulkader, R. S., Abdulle, A. M., Abebo, T. A., Abera, S. F., \& Aboyans, V. (2017). Global, regional, and national incidence, prevalence, and years lived with disability for 328 diseases and injuries for 195 countries, 1990-2016: a systematic analysis for the global burden of disease study 2016. The Lancet, 390(10100), 1211-1259.

Walsh, T. P., Arnold, J. B., Evans, A. M., Yaxley, A., Damarell, R. A., \& Shanahan, E. M. (2018). The association between body fat and musculoskeletal pain: a systematic review and meta-analysis. BMC Musculoskeletal Disorders, 19(1), $1-13$. 